УДК 637.146:67:613.2

\title{
RATIONALE OF THE COMPOSITION \\ AND DEVELOPMENT OF DESSERT ENZYMED PRODUCTS TECHNOLOGIES OF FUNCTIONAL PURPOSE WITH THE USE OF PLANT FILLERS
}

\author{
A. Solomon \\ Vinnytsia National Agrarian University \\ T. Semko \\ Vinnytsia Trade and Economic Institute of Kyiv National University of Trade and \\ Economics \\ H. Nozhechkina-Eroshenko \\ Poltava State Agrarian Academy
}

\begin{tabular}{|c|c|}
\hline & ABSTRACT \\
\hline $\begin{array}{l}\text { Key words: } \\
\text { bifidobacteria, } \\
\text { lactobacilli, } \\
\text { growth promoters, } \\
\text { stabilizers, } \\
\text { plant fillers, } \\
\text { biological value }\end{array}$ & $\begin{array}{l}\text { The fermented soul-milk dessert products of functional ori- } \\
\text { entation acquire in Ukraine of all greater popularity. The ferme- } \\
\text { nted dairies are the basic suppliers of microorganisms of probi- } \\
\text { otic, that assist support and proceeding in microbal ecology of } \\
\text { man. To the cultures of probiotic, that provide an useful effect on } \\
\text { the organism of consumer and normalize composition and functi- } \\
\text { ons of microflora of gastrointestinal tract, such types of лакто- }\end{array}$ \\
\hline $\begin{array}{l}\quad \text { Article history: } \\
\text { Received } 07.02 .2020 \\
\text { Received in revised form } \\
14.06 .2020 \\
\text { Accepted } 30.06 .2020\end{array}$ & $\begin{array}{l}\text { belong and bifidobacterium, as Lactobacillus of acidophilus, } \\
\text { Lactobacillus of casei, Bifidobacterium of spp. (B. of adolescen- } \\
\text { tis, B. animalis ssp. lactis, B. bifidum, B. longum, B. breve). Bifi- } \\
\text { dobacterium - one of the most essential groups of microorga- } \\
\text { nisms to the bowels, that prevail in the anaerobic flora of colon. }\end{array}$ \\
\hline $\begin{array}{l}\text { Corresponding author: } \\
\text { semko1965@ukr.net }\end{array}$ & $\begin{array}{l}\text { It should be noted that for most microorganisms that are the re- } \\
\text { presentatives of normal microflora of intestinal highway of hu- } \\
\text { man, milk is an unfavorable environment for their development. } \\
\text { The article investigates and substantiates the composition of } \\
\text { pro- and prebiotics, the influence of the bifidostimulant compo- } \\
\text { nent and the stabilizing system on the quality indices of ferme- } \\
\text { nted dessert products, and the technologies of dairy desserts ba- } \\
\text { sed on the consortium of bifidobacteria and lactobacilli. Since } \\
\text { milk is an unfavorable environment for the development of most } \\
\text { microorganisms - representatives of the normal bacterial flora } \\
\text { of the gastrointestinal tract of man and does not contain the low } \\
\text { molecular weight compounds required for the development of } \\
\text { microorganisms, and most bacteria of the genus Lactobacillus, } \\
\text { Lactococcus and Bifidobacterium are related to in milk oxygen, } \\
\text { they develop very slowly in milk. The conducted researches have } \\
\text { allowed to develop recipes and technologies of production of fer- } \\
\text { mented desserts on milk and milk-grain basis, with the use of bi- } \\
\text { fidobacteria and lactobacilli, as well as bifidostimulants, structure- } \\
\text { forming agents and fruit-berry fillers, which retain high biolo- } \\
\text { gical value, } 15 \text { flavors and aromatic texture. }\end{array}$ \\
\hline
\end{tabular}

DOI: $10.24263 / 2225-2916-2020-27-10$

(C) А. М. Соломон, Т. В. Семко, Г. М. Ножечкіна-Срошенко, 2020 


\title{
ОБҐРУНТУВАННЯ СКЛАДУ І РОЗРОБЛЕННЯ ТЕХНОЛОГІЙ ДЕСЕРТНИХ ФЕРМЕНТОВАНИХ ПРОДУКТІВ ФУНКЦІОНАЛЬНОГО ПРИЗНАЧЕННЯ 3 ВИКОРИСТАННЯМ РОСЛИННИХ НАПОВНЮВАЧІВ
}

\author{
А. М. Соломон, канд. техн. наук \\ Вінницький національний аграрний університет \\ Т. В. Семко, канд. техн. наук \\ Вінницький торговельно-економічний інститут Київського національного \\ торговельно-економічного університету
}

Г. М. Ножечкіна-Єрошенко, канд. техн. наук

Полтавська державна аграрна академія

У статті науково досліджено й обгрунтовано склад про- і пребіотиків, вплив біфрідостимулюючої складової і стабілізуючої системи на показники якості фрерментованих десертних продуктів, розроблено технології кисломолочних десертів на основі консорціуму біфрідо- і лактобактерій. Проведені дослідження дали змогу розробити рецептури й технології виробництва фрерментованих десертів на молочній і молочно-борошняній основі з використанням біфрідобактерій та лактобактерій, а також біфрідостимуляторів, структуроутворювачів і фрруктово-ягідних наповнювачів, які зберігають високу біологічну цінність, ніжну текстуру, смак та аромат протягом 15 днів.

Ключові слова: біфідобактерії, лактобактерії, стимулятори росту, стабілізатори, рослинні наповнювачі, біологічна цінність.

Постановка проблема. Ферментовані молочні продукти є основними постачальниками пробіотичних мікроорганізмів, які сприяють відновленню мікрофлори шлунково-кишкового тракту людини. Всі види біфідобактерій і окремі види лактобактерій, такі як Lactobacillus acidophilus, Lactobacillus casei subsp. casei, Bifidobacterium spp. (B. adolescentis, B. animalis, B. bifidum, B. longum, B. breve) та інші належать до пробіотичних культур, які позитивно впливають на споживача і нормалізують склад та функції бактеріальної флори шлунково-кишкового тракту.

Біфідобактерії - одна з основних груп мікроорганізмів, що домінують в анаеробній флорі кишківника. Міжнародна молочна федерація вважає, що біобазова продукція - це сполуки, що містять щонайменше $1 \cdot 10^{7}$ біфідобактерій в $1 \mathrm{~cm}^{3}$ [3; 4].

Для створення молочних десертних ферментованих продуктів функціонального призначення, які здатні підтримати і відновити мікробну екологію людини, забезпечити активацію життєво важливих функцій організму, підвищити опір агресивним умовам навколишнього середовища, необхідно дослідити фактори, визначити вплив стабілізуючої системи на реологічні властивості десертних ферментованих продуктів з синбіотичними властивостями на основі про- і пребіотиків, що дасть змогу надати десертним продуктам функціональної спрямованості.

Створення симбіотичних функціональних продуктів з використанням пребіотиків - інгредієнтів природного походження, які здатні стимулювати розвиток пробіотичних культур, відноситься до перспективних напрямків розширення асортименту функціональних продуктів харчування. 
Для створення функціональних ферментованих продуктів необхідно визначити склад високоефективних культур мікроорганізмів, які поряд з високою продуктивністю володіють високою та різноманітною біохімічною активністю. Правильний вибір біологічно активних штамів біфідо- та лактокультур для виробництва ферментованих молочних продуктів дасть змогу отримати якість, що відповідає вимогам нормативних документів за органолептичними і фізико-хімічними показниками .

Експертами встановлено можливість комбінованого використання біфідобактерій і лактобактерій. Визначено, що значна кількість молочної кислоти, яка утворюється у процесі життєдіяльності стрептококів і бацил, стимулює ріст bifidobacterim-флори у молоці, сприяє збільшенню кількості активних клітин та інтенсивному накопиченню продуктів метаболізму [8].

Біфідобактерії регулюють якісний і кількісний склад нормальної мікрофлори кишківника, перешкоджають росту і запобігають розмноженню патогенної, гнильної та аерогенної флори, відновлюють пошкоджену структуру слизової оболонки кишківника. Разом з іншими представниками нормальної кишкової флори, біфідобактерії беруть участь у перетравлюванні і всмоктуванні поживних елементів, синтезі вітамінів групи B, вітаміну D, фолієвої та нікотинової кислот, сприяють синтезу незамінних амінокислот, кращому поглинання вітаміну D і кальцію, підвищенню функції організму до захисту - імунітету, стимулюють активність лізоциму та синтез антитіл [9].

Створення синбіотиків (комплекс про- і пребіотиків) та виготовлення на їх основі продуктів харчування $є$ ефективним способом нормалізації кишкової бактеріальної флори і стимулює розвиток власної кишкової бактеріальної флори та підвищення захисних функцій кишківника.

Ферментовані молочні десерти функціонального призначення дуже популярні в Україні. У процесі їх виробництва використовується широкий асортимент ароматизаторів і стабілізаторів, які покращують смак і запах продукту, регулюють процеси структуроутворення.

Розробка технологій десертів на основі молочної сировини з використанням фруктових та овочевих наповнювачів, які збагачують продукти вітамінами, мінералами, поліфенолами, дає змогу значно підвищити біологічну цінність і розширити асортимент функціональних десертних продуктів. Як наповнювачі використовують різноманітні фруктові та ягідні соки, пюре, сиропи, натуральні фрукти та ягоди у замороженому вигляді або у вигляді цукатів.

Аналіз останніх досліджень і публікацій. Лактококи та стрептококи характеризуються високим ступенем утворення кислот, але лактобацили Lactobacillus delbrueckii subsp. bulgaricus i Lactobacillus acidophilus перевищують інші молочнокислі бактерії за рівнем кислотоутворення. На думку вчених, штами молочнокислих стрептококів Lactococcus lactis subsp. lactis, Lactococcus lactis subsp. cremoris, Streptococcus thermophilus, Lactobacillus acidophilus виробляють переважно L(+)-молочну кислоту, яка фізіологічно важлива для організму людини. Lactobacillus acidophilus інгібують шкідливу бактеріальну флору (сальмонелу, стафілококи тощо) завдяки здатності продукувати антибіотики лактоцидину та ацидофілу, які посилюються при контакті з молочною кислотою [8; 15].

Метою статті $\epsilon$ наукове обгрунтування складу заквашувальних препаратів i розроблення технологій кисломолочних десертних продуктів функціонального призначення, збагачених біологічно активними речовинами рослинного походження. 
Матеріали і методи. Використано штами лактобактерій S. Thermophilus CT-14, Lactobacillus acidophilus, а також найбільш поширені штами біфідобактерій, притаманні організму людини, — Bifidobacterium bifidum 791, Bifidobacterium longum subsp. longum B 379 M, Bifidobacterium adolescentis B-1.

Дослідження біохімічних, фізико-хімічних і органолептичних показників кисломолочних ферментованих продуктів здійснювали загальноприйнятими методами аналізу. Використані методи викладені у відповідних стандартах і керівних документах 3 технохімічного, мікробіологічному контролю виробництва молока i молочних продуктів. Усі отримані результати досліджень обробляли методами математичної статистики.

У результаті проведених досліджень виявлено, що підібрані штами біфідобактерій у процесі розвитку є стійкими до високих концентрацій жовчі, фенолу, вони розмножуються в середовищі низького та високого рН, не утворюють каталази та сірководню, не відновлюють нітрати та нітрити і не розчиняють желатин [19].

Консорціум підібраних біфідобактерій у співвідношенні 1:1:1 оцінювали за резистентністю в умовах, близьких до середовища шлунку $(\mathrm{HCl}, \mathrm{pH} 2-3)$ протягом 5 год, і в умовах, близьких до зберігання готових молочних десертів (pH 3-4), протягом 24 годин.

Результати і обговорення. При контакті із соляною кислотою при рН 3 кількість життєздатних клітин біфідобактерії консорціуму зменшилась на 5,2\%, при pH 2 на - 9,8\%. Під час зберігання молочних продуктів у контакті з молочною кислотою при рН 4 кількість життєздатних клітин біфідобактерій була знижена на 3,4\%, при рН 3 на - 6,2\%. На підставі експериментальних даних можемо побачити, що збереження активності біфідобактерій при проходженні через шлунковокишковий тракт надає можливість прогнозувати виживання біфідобактерій у складі ферментованого молочного десерту під час зберігання готової продукції до експериментального кінцевого терміну.

Досліджено зміну технологічних властивостей консорціуму пристосованих лакто- та біфідобактерій та їх складу протягом 6 год зберігання (табл. 1).

Таблиия 1. Технологічні властивості композицій мікроорганізмів

\begin{tabular}{|c|c|c|c|c|}
\hline \multirow[t]{2}{*}{$\begin{array}{c}\text { Композиції } \\
\text { мікроорганізмів }\end{array}$} & \multirow{2}{*}{$\begin{array}{c}\text { Активна } \\
\text { кислотність } \\
\text { (рH) }\end{array}$} & \multirow{2}{*}{$\begin{array}{c}\text { Енергія } \\
\text { кислотоутворення } \\
\text { при бродінні, }{ }^{\circ} \mathrm{T}\end{array}$} & \multicolumn{2}{|c|}{$\begin{array}{c}\text { Кількість життєздатних } \\
\text { клітин у згустку, } \\
\text { Lg CFU / } \text { см }^{3}\end{array}$} \\
\hline & & & бактерії & лактобактерії \\
\hline $\begin{array}{c}\text { Консорціум } \\
\text { лактобацил } \\
\text { (L.acidophilus + Str. } \\
\text { thermophilus) }(1: 1)\end{array}$ & $4,5 \pm 0,2$ & $73 \pm 0,5$ & - & $7,2 \pm 0,2$ \\
\hline $\begin{array}{c}\text { Консорціум } \\
\text { біфідобактерій } \\
\text { (B. bifidum }+ \\
\text { B. longum }+ \\
\text { B. adolescentis }) \\
(1: 1: 1) \\
\end{array}$ & $4,7 \pm 0,2$ & $66 \pm 0,3$ & $8,9 \pm 0,2$ & 一 \\
\hline $\begin{array}{c}\text { Композиція } \\
\text { (консорціум } \\
\text { біфідобактерій та } \\
\text { консорціум } \\
\text { лактобактерій) } \\
(2: 1) \\
\end{array}$ & $4,6 \pm 0,2$ & $69 \pm 0,5$ & $9,5 \pm 0,3$ & $8,0 \pm 0,2$ \\
\hline
\end{tabular}


Встановлено, що при використанні композиції консорціумів лакто- і біфідобактерій, енергія кислотоутворення, порівняно із консорціумом біфідобактерій, зростає. Але порівняно з консорціумом лактобактерій зменшується, що є сприятливим явищем для росту біфідобактерій.

Важливою характеристикою штамів пробіотичних бактерій, які використовуються при виробництві функціональних продуктів, є антагоністична дія щодо патогенних і умовно-патогенних мікроорганізмів. В умовах in vitro досліджено антагоністичну активність консорціумів штамів біфідо- і лактобактерій та композиції.

У процесі розвитку біфідобактерій важливу роль відіграють поживні речовини, які накопичуються в результаті життєдіяльності штамів молочнокислих бактерій, збільшуючи кількість життєздатних колонієутворюючих клітин біфідобактерій.

Ми використовували біфідобактерії-пробіотики і стимулятори росту та розвитку - фруктозу, лактулозу, концентрат артишоку, як джерело інуліну, а також пектин, желатин, крохмаль, крупи, рис та вівсяну муку як стабілізуючі системи.

Під час ферментації стерилізованого знежиреного молока консорціум біфідобактерій протягом 6 год активізували, змішуючи з такими біфідостимуляторами: фруктозою до досягнення $\mathrm{pH}-4,64$; лактулозою до $\mathrm{pH}-4,6$; інуліном до $\mathrm{pH}-$ 4,5 ; без стимуляторів для біфідобактерій значення $\mathrm{pH}$ складало 4,7 , в той час як титрована кислотність становила, відповідно, $68^{\circ} \mathrm{T}, 72^{\circ} \mathrm{T}, 74^{\circ} \mathrm{T}$ і $52^{\circ} \mathrm{T}$.

Лактулоза є найбільш дослідженим пребіотиком у світі. Відмінність лактулози від інших цукрів полягає в тому, що вона не перетравлюється у верхньому відділку шлунково-кишкового тракту, а надходить у товсту кишку в незмінному вигляді, де слугує стимулятором росту і розвитку власної біфідо-флори «господаря». В той же час лактулоза не слугує субстратом для патогенної мікрофлори, зокрема кишкової палички і сальмонели [20; 21$]$.

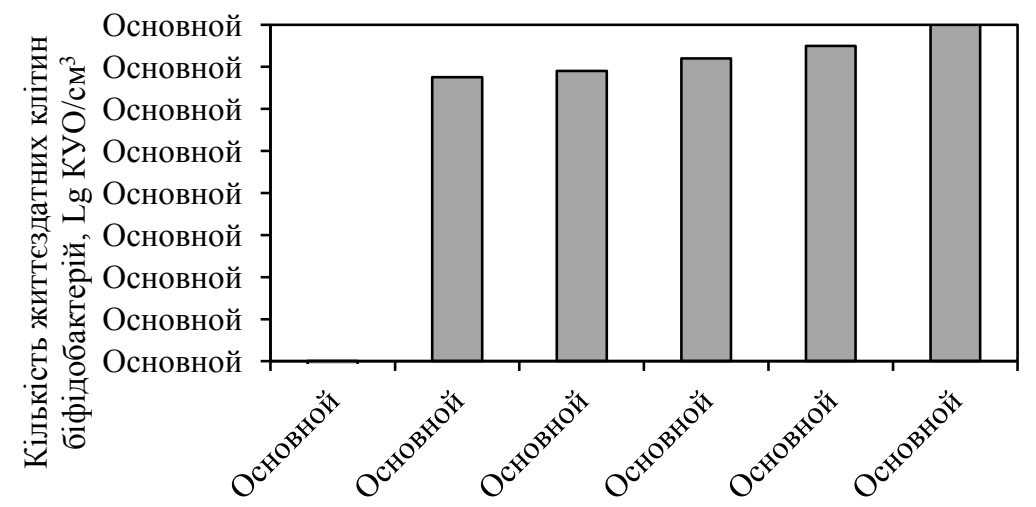

Масова частка фруктози, \%

Рис. 1. Залежність кількості життсздатних клітин біфідобактерій у кисломолочних згустках від масової частки фруктози:

$1-0,1 \% ; 2-0,2 \% ; 3-0,3 \% ; 4-0,4 \% ; 5-0,5 \%$ 
Клінічними дослідженнями доведено, що лактулоза може бути рекомендована як пребіотична добавка при виготовлені ферментованих кисломолочних продуктів функціональної спрямованості при захворюваннях шлунково-кишкового тракту. Залежність кількості життєздатних клітин біфідобактерій в отриманих згустках від масової частки інуліну, як біфібостимулюючого фактора, наведена на рис. 2.

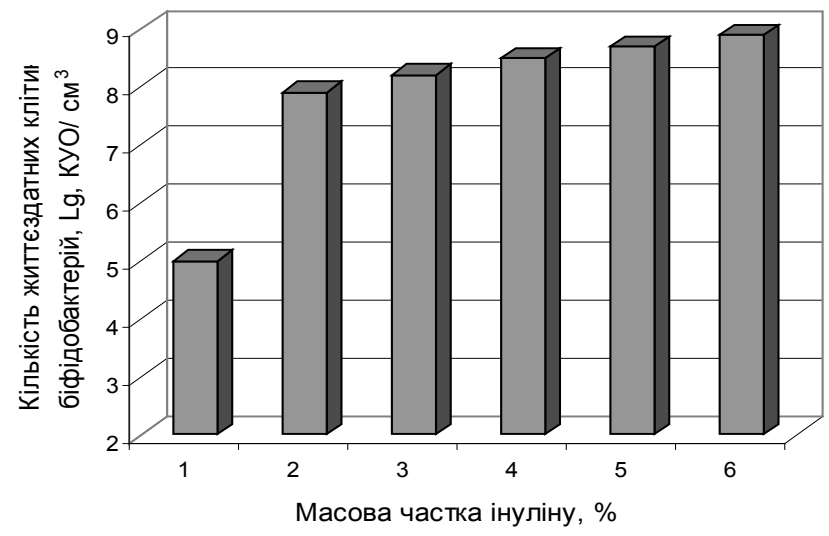

Рис. 2. Залежність кількості життєздатних клітин біфідобактерій у кисломолочних згустках від масової частки інуліну: 1 - контроль; $2-0,1 \% ; 3-0,2 \% ; 4-0,3 \% ; 5-$ $0,4 \% ; 6-0,5 \%$

При використанні як біфідостимулятора інуліну відбувається значне зростання кількості життєздатних клітин біфідобактерій, що можна пояснити хімічним складом концентрату топінамбура, вуглеводи якого представлені інуліном, фруктозою і iї похідними. Крім того, до складу концентрату топінамбура входять повноцінні білки, вітаміни, мінеральні речовини, пектини, які теж сприяють покращенню росту і розвитку біфідобактерій. Тож представлені результати $з$ дослідження дії обраних біфідостимуляторів свідчать, що добавки фруктози, лактулози та інуліну навіть у кількості 0,1% здатні забезпечити пробіотичний ефект, стимулювати ріст і розвиток біфідобактерій у знежиреному стерилізованому молоці в кількості значно вищій, ніж $1 \cdot 10^{6} \mathrm{KУO} / \mathrm{cm}^{3}$.

На думку фахівців, лактулоза і лактоза гідролізуються до моноцукрів, які виконують роль енергетичного матеріалу для розвитку біфідобактерій. Збродження моноцукрів відбувається фруктозо-глюкозним шляхом, тому передусім зброджується фруктоза, а глюкоза й галактоза ізомеризуються у фруктозу і також зброджуються до молочної й оцтової кислот [23; 24].

Як показали дослідження, при використанні біфідостимуляторів продукт набував більш низького значення активної кислотності і підвищеного значення титрованої кислотності, що пояснюється збільшенням активності біфідобактерій і утворенням оцтової кислоти, яка є досить сильним електролітом.

Для визначення раціональної концентрації сухого знежиреного молочного залишку (СЗМ3) використовували сухе знежирене молоко (NFDM), як молочну знежирену основу (MSNF) продуктів. Підвищення вмісту СЗМЗ сприяє збільшенню кількості контактів між казеїновими міцелами під час коагуляції на одиницю об'єму дисперсійного середовища і призводить до їх інтенсивної взаємодії в процесі утворення згустку, збільшення в'язкості продукту та покращення його консистенції. Підвищення концентрації MSNF у поживному середовищі суттєво стимулює ріст і 
розвиток біфідобактерій за рахунок збільшення вмісту амінокислот [10]. Це, у свою чергу, підвищує титр біфідобактерій і збільшує казеїнат-кальцій-фосфатний комплекс (ККФК) у молочній основі — утворює буферну систему, яка пригнічує наростання кислотності при збільшенні біомаси біфідобактерій. У ролі стабілізаторів молочної структури десертів використовували пектин, желатин, крохмаль, вівсяне та рисове борошно.

Важливою складовою будь-якого продукту виступають смакові наповнювачі, які не тільки формують органолептичні властивості, але й збагачують продукти біологічно-активними інгредієнтами - вітамінами, мінеральними речовинами, поліфенолами, підвищують опір організму несприятливим умовам навколишнього середовища.

Рецептуру десертних ферментованих продуктів функціональної спрямованості 3 масовою часткою жиру 2,5\% наведено в табл. 2 .

Таблиця 2. Рецептури десертних ферментованих продуктів на молочній основі

\begin{tabular}{|c|c|}
\hline Сировина & Масова частка сировини, кг \\
\hline Молоко знежирене Ж $=0,05 \%$ & 709,0 \\
\hline Молоко сухе знежирене Ж $=1 \%$ & 61,8 \\
\hline Вершки Ж $=35 \%$ & 34,4 \\
\hline Фруктоза & 50,0 \\
\hline Крохмаль желеподібний & 40,0 \\
\hline Желатин & 10,0 \\
\hline Сироп «Лактусан» & 20,0 \\
\hline Пектин яблучний & 3,0 \\
\hline Ванілін & 0,1 \\
\hline Натрій лимоннокислий & 1,2 \\
\hline Закваска & 50,0 \\
\hline Сік плодово-ягідний & 20,5 \\
\hline Всього: & 1000,0 \\
\hline
\end{tabular}

Пектин активізує розвиток біфідобактерій, розмноження і вирощування нормальної бактеріальної флори шлунково-кишкового тракту і має детоксикаційні та радіозахисні властивості [10]. У контакті з пектином кількість життєздатних клітин біфідобактерій протягом 24 год збільшується $31 \cdot 10^{4} \mathrm{KУO} / \mathrm{cm}^{3}$ до $2,5 \cdot 10^{8} \mathrm{KУO} / \mathrm{cm}^{3}$ порівняно 3 контролем, у якому кількість біфідобактерій збільшується 3 $1 \cdot 10^{4} \mathrm{KOE} / \mathrm{cm}^{3}$ до $1 \cdot 210^{7} \mathrm{KУO} / \mathrm{cm}^{3}$.

Желатин як білкова речовина в кислому середовищі створює позитивний ефект; він зв'язує вологу і утворює твердий гель при низькому рН. Здатність желатину зв'язувати вільну вологу й утворювати щільні згустки та гелі шляхом формування тривимірної сітчастої структури має важливе значення у молочній промисловості, оскільки знижує ризик синерезису у виготовлених продуктах. У результаті збільшується термін придатності, зменшується собівартість і покращується якість готового продукту.

Крохмаль $є$ нейтральним полісахаридом і служить як структурним зв'язуючим агентом, так і стабілізатором отриманих структур. Крохмаль підвищує вологоутримуючу здатність молочної основи, але це впливає на здатність біфідобактерій до кислотоутворення. Так, у контрольному зразку без крохмалю титрована кислотність становить майже $88^{\circ} \mathrm{T}$, а у зразках із вмістом крохмалю $5,0 \%$ - титрована кислотність менше $76^{\circ} \mathrm{T}$.

Можемо вважати, що крохмаль $є$ нейтральним гідроколоїдом і безпосередньо не впливає на процес бродіння, але зв'язує вологу і підвищує в'язкість, що перешкоджає розвитку мікрофлори та уповільнює процес бродіння. Встановлено, що 
використання стабілізаторів у раціональній кількості (пектину - 0,3\%, желатину - 3\%, крохмалю - 4\%) надає можливість отримати структуру, властиву кисломолочним продуктам, забезпечити необхідну вологу та в'язкість, збільшити кількість життєздатних клітин біфідобактерій і запобігти агрегації молочного білка при використанні фруктових та ягідних наповнювачів.

У ролі стабілізаторів використовували вівсяне і рисове борошно, призначене для дитячого харчування, без ферментативної ліпази. Рисове борошно відрізняється від вівсяного борошна підвищеним вмістом крохмалю, мінералами і меншим вмістом білків та жирів. Крохмальне рисове борошно добре набухає, його об'єм збільшується в 5-7 разів порівняно з вівсяним борошном, об'єм якого збільшується лише в 4,5 раза. Для дослідів використовували суміш рисового борошна та вівсяного у співвідношенні $1: 1$. Вівсяне борошно збагачує суміш білками та жирами, а рисовий борошняний крохмаль забезпечує високу вологопоглинальну здатність.

Вищевказана двокомпонентна стабілізуюча система дає змогу отримати гель 3 ніжною однорідною консистенцію і глянцевою поверхнею, типовою для молочних десертних продуктів, таких як пасти та пудинги. Після 18 год бродіння титрована кислотність контрольних зразків становить $82^{\circ} \mathrm{T}$, активна кислотність pH 4,5. У тестових зразках титрована кислотність становить, відповідно, $88^{\circ} \mathrm{T}$ i $\mathrm{pH} 4,4$. Згусток починає утворюватися після 12 год бродіння, коли титрована кислотність у контрольних та експериментальних зразках дорівнює, відповідно, $72^{\circ} \mathrm{T}$ i $76^{\circ} \mathrm{T}$, а активна кислотність — $\mathrm{pH}$ 4,7 і pH 4,6 відповідно. Суміш 3 вівсяної та рисової муки стимулює ріст і проліферацію біфідобактерій, збільшуючи кількість життєздатних клітин під час бродіння від $1 \cdot 10^{2}$ до $1 \cdot 10^{9} \mathrm{KУO} / \mathrm{cm}^{3}$.

Встановлено, що для пастеризації молочної основи, нормалізованої за білком і жиром, доцільно використовувати режим $(90 \pm 2)^{\circ} \mathrm{C}$ з витримкою 2 хвилини. 3 огляду на те, що молочна основа і суміш вівсяного та рисового борошна можуть бути засіяні спорами шкідливих мікроорганізмів, температуру пастеризації встановлювали $(95 \pm 2)^{\circ} \mathrm{C} 3$ витримкою 5 хвилин.

У виробництві молочних десертів на основі знежиреного і нормалізованого молока ми додавали в суміш підготовлені стимулятори росту біфідобактерій i стабілізатори структури у встановленій раціональній кількості.

Закінчення процесу ферментації визначали за показниками титрованої і активної кислотності. В охолодженому до $(4 \pm 2)^{\circ} \mathrm{C}$ продукті визначали вплив використаних біфідостимуляторів і стабілізаторів на розвиток пробіотиків, титровану, активну кислотність та фізико-хімічні властивості.

Процес гелеутворення починається на третій і майже закінчується на п'ятій годині процесу ферментації. Тривалість lag- фази при ферментації десертних продуктів з гелеподібною структурою становить 1 год, що свідчить про правильно визначений склад і кількість використаних біфідостимуляторів. Найбільш різке підвищення титрованої і зниження активної кислотності відбувається з третьої по п’яту годину ферментації.

Титрована кислотність дослідних зразків через 6 год ферментації становить $72^{\circ} \mathrm{T}$, контрольних - $85^{\circ} \mathrm{T}$, активна кислотність, відповідно, $-4,7$ і 4,5. Кількість життєздатних клітин біфідобактерій у кисломолочних згустках після 6 год ферментації збільшується $31 \cdot 104 \mathrm{KУO} / \mathrm{cm}^{3}$ до $2,5 \cdot 10^{10} \mathrm{KУO} / \mathrm{cm}^{3}$ порівняно 3 контролем, в якому кількість біфідобактерій зростає до $2 \cdot 10^{8} \mathrm{KУO} / \mathrm{cm}^{3}$.

В'язкість продуктів визначали за допомогою віскозиметра «Reotest-2» (градієнт швидкості зсуву $\left.D r=0,3333 \mathrm{c}^{-1}\right)$. Встановлено, що процес структуроутворення при ферментації десертного продукту на молочній основі майже закінчується при досягненні в'язкості $1,65 \cdot 10^{2}$ Па·с. 
Важливою складовою будь-якого продукту виступають смакові наповнювачі, які не тільки формують органолептичні властивості, але й збагачують продукти біологічно-активними інгредієнтами - вітамінами, мінеральними речовинами, поліфенолами, підвищують опір організму несприятливим умовам навколишнього середовища. Як збагачувачі найчастіше використовують плодово-ягідні соки або сиропи, які рівномірно розподіляються по всьому об'єму продукту. При виготовлені кисломолочних продуктів функціональної спрямованості доцільно використовувати тільки соки прямого віджиму з вітамінів, поліфенолів, мінеральних речовин тощо.

Складність використання плодово-ягідних збагачувачів пов'язана 3 тим, що внесення добавок до процесу заквашування може порушити процес ферментації молочної основи, змінити колір, смак і реологічні властивості готової продукції, що позначається на тривалості зберігання готової продукції. Експериментально доведено, що виробництво десертних ферментованих продуктів доцільно проводити термостатним способом, а плодово-ягідні збагачувачі краще вносити після заквашування під час процесу перемішування.

При додаванні фруктових та ягідних наповнювачів потрібно враховувати, що вони мають низьку кислотність, тому може відбуватися ущільнення тривимірної структурної сітки білкового гелю, порушення структури солодких ферментованих продуктів і виникнення синерезису.

Результати досліджень основних показників якості ферментованих десертів 3 фруктовими наповнювачами відразу після охолодження до температури зберігання $(3 \pm 1)^{\circ} \mathrm{C}$ наведено в табл. 3 .

Процес сквашування експериментальних зразків триває 5-6 годин. Отримані згустки симбіотичних продуктів щільні, текстура однорідна, ніжна, желатиноподібна та помірно в'язка. Смак чистий, приємний, із запахом фруктових наповнювачів.

Результати експериментальних досліджень стали основою для розроблення нових технологій кисломолочних десертів функціонального призначення.

Було проведено дослідження змін кількості життєздатних біфідобактерій під час зберігання готового продукту протягом 25 днів при температурі $(4 \pm 2)^{\circ} \mathrm{C}$. Встановлено, що протягом перших 10 днів кількість життєздатних біфідобактерій практично не змінюється, протягом наступних 5 днів починається поступове відмирання клітин біфідобактерій, але їх вміст у продуктах залишається високим.

Таблиия 3. Показники якості десертних продуктів з фруктовими наповнювачами

\begin{tabular}{|c|c|c|c|c|}
\hline \multirow{2}{*}{ Показники } & \multicolumn{4}{|c|}{ Десертні продукти } \\
\cline { 2 - 5 } & \multicolumn{2}{|c|}{ на молочній основі } & \multicolumn{2}{c|}{$\begin{array}{c}\text { на молочно-борошняній } \\
\text { основі }\end{array}$} \\
\cline { 2 - 5 } & Контроль & Тест & Контроль & Тест \\
\hline Активна кислотність, pH & $4,5 \pm 0,1$ & $4,67 \pm 0,1$ & $4,52 \pm 0,1$ & $4,64 \pm 0,1$ \\
\hline Титрована кислотність, ${ }^{\circ} \mathrm{T}$ & $77,5 \pm 0,2$ & $75,2 \pm 0,2$ & $78 \pm 0,2$ & $78,8 \pm 0,2$ \\
\hline $\begin{array}{c}\text { Кількість життєздатних клітин } \\
\text { біфідобактерій, }, \mathrm{Lg} \mathrm{KУО/} \mathrm{см}\end{array}$ & $9,2 \pm 2$ & $9,8 \pm 2$ & $10,1 \pm 2$ & $10,5 \pm 2$ \\
\hline Тривалість коагуляції, годин & $5,0 \pm 0,5$ & $5,5 \pm 0,5$ & $5,0 \pm 0,5$ & $5,5 \pm 0,5$ \\
\hline В'язкість, $\eta \cdot 10^{3}$, Па·с & $1,89 \pm 0,2$ & $1,93 \pm 0,2$ & $1,91 \pm 0,2$ & $1,95 \pm 0,2$ \\
\hline Синерез, см ${ }^{3}$ & Відсутній & Відсутній & Відсутній & Відсутній \\
\hline
\end{tabular}

Дослідження змін реологічних властивостей молочних і молочно-борошняних продуктів під час зберігання показало, що протягом перших п'яти днів зберігання отримані структури посилюються і в'язкість ферментованих десертних 
продуктів зростає в результаті процесу комплексного утворення гідроколоїдів, а також завдяки адсорбції поліфенольних речовин фруктово-ягідної сировини на поверхні білків та полісахаридів з утворенням складних структур, що ущільнюють структуру.

Висновки. Встановлено, що структура контрольних зразків десертів не змінюється протягом 15 днів, тестових зразків - протягом 20 днів, 3 подальшим поступовим руйнуванням структури, а в окремих зразках спостерігається незначне відділення вологи у вигляді окремих крапель. Через 25 днів синерезис солодких молочних продуктів становить $1,2 \mathrm{~cm}^{3}$, продуктів на молочно-борошняній основі - 0,8 $\mathrm{cm}^{3}$. Пробіотичні властивості як контрольних, так і тестових зразків підтверджуються тим, що протягом 20 днів зберігання кількість життєздатних біфідобактерій була не нижче ніж $1 \cdot 10^{9} \mathrm{KУO} / \mathrm{cm}^{3}$, але з огляду на те, що через 10 днів зберігання клітини біфідобактерій починають гинути, час зберігання ферментованих солодких продуктів обмежується 15 днями.

Проведені дослідження дали змогу розробили рецептури й технології виробництва ферментованих десертів на молочній і молочно-борошняній основі з використанням біфідобактерій та лактобактерій, а також біфідостимуляторів, структуроутворювачів і фруктово-ягідних наповнювачів, які зберігають високу біологічну цінність, ніжну текстуру, смак та аромат протягом 15 днів.

\section{ЛITЕРАТУРА}

1. Roberfroid M. B. Global view on functional foods: European perspectives / Roberfroid M. B. // British J. Nutr. — 2002. - Vol. 88 (S2). - P. 133-138.

2. Roberfroid M. B. Prebiotics and probiotics: are they functional foods? / Roberfroid M. B. // Am. J.Clin.Nutr. - 2000. — № 6. - P. 1682-1687.

3. Rolfe R. D. The role of probiotic cultures in the control of gastrointestinal health / Rolfe R. D. // J. Nutrit. - 2000. — № 2. - P. 396-402.

4. Shah N. P. Probiotic bacteria: selective enumeration and survival in dairy foods / Shah N. P. // J. Dairy Sci. — 2000. — № 4. — P. 894-907.

5. Sanders M. E. Considerations for use of probiotic bacteria to modulate human health / Sanders M. E. // J. Nutrit. — 2000. — № 2. - P. 384-390.

6. Ботина С. Г. Штаммы Streptococcus thermophilus, ферментующие галактозу / Ботина С. Г. // Молочная пром-сть. - 2008. - № 4. - С. 54-56.

7. Richardson D. P. Functional Food and Health Claims / Richardson D. P. // The world of Functional ingredients. - 2002. - Vol. 9. - P. 12-20.

8. Schrezenmeir J. Probiotics, prebiotics and synbiotics - approaching a definition / Schrezenmeir J., M. de Vrese.// Am. J.Clin.Nutr. — 2001. — № 2. - P. 361-364.

9. Смирнов В. В. Пробиотики на основе живых культур / Смирнов В. В., Коваленко Н. К., Подгорный В. С., Сорокулова И. Б. // Микроб. журн. - 2002. - № 4. Т. 64.- С. 62-80.

10. Kailsapathy K. Survival and therau-peutic potential of probiotic organisms with reference to Lactobacillus acidophilus and Bifidobacterium spp. / Kailsapathy K., Chin J. // Immunology and Cell Biology. - 2000. - Vol. 78. - P. 80-88.

11. Танащук С. В. Основные характеристики лактулозы, как функционального ингредиента / Танащук С. В., Савченко О. А., Подосинников А. Р. // Молочное Дело. — 2005. — № 9. — С. 38 39.

12. Ярощук О. А. Фруктовые десерты с пектином на основе молочной сыворотки / Ярощук О. А., Овчарова Г. П., Донченко Л. В. // Переработка молока. — 2007. — № 12. - С. 14-15.

13. Семенихина В. Ф. Технологические аспекты использования бифидобактерий для кисломолочных продуктов / Семенихина В. Ф., Рожкова И. В., Бегунова А. В. // Молочная промсть. - 2009. - № 12. - С. 9-11.

14. Храмцов А. Г. Комплексная система пробиотически-сорбционной направленности / Храмцов А. Г., Садовой В. В., Самылина В. А. // Изв. ВУЗов. Пищ. технология. — 2005. № 4. - C. $40-42$.

15. Дідух Н. А. Симбіотичний комплекс для виробництва ацидофільних кисломолочних продуктів з підвищеними функціональними властивостями / Дідух Н. А., Могилянська Н. О., 
Власенко О. В. // Зб. наук. пр. ОНАХТ. - Одеса: ОНАХТ, 2009. - Вип. 36. Том. 2. — С. 129133.

16. Наследова Л. Ф. Еще раз о лактулозе / Наследова Л. Ф. // Молочная пром-сть. — 2009. — № 9. - С. $68-69$.

17. Храмцов А. Г. Технологическая платформа отечественного пребиотика лактулозы / Храмцов А. Г., Евдокимов И. А., Рябцева С. А., Кожевникова О. Н. // Молочная пром-сть. 2009. — № 12. - С. 53-56.

18. Полянский К. К. Пищевые волокна в молочних продуктах / Полянский К. К., Глаголева В. Э., Ряховский Ю. В. // Молочная пром-сть. - 2009. - № 12. - С. 9-11.

19. Станкевич Г. М. Оптимізація параметрів гомогенізації молочно-жирових сумішей для геродієтичних напоїв / Станкевич Г. М., Дідух Г. В. // Харчова наука і технологія. — 2009. № 2(7). - С. 69-71.

20. Дидух Н. А. Симбиотические комплексы для производства ферментированных молочных геронапитков [Текст] / Н. А. Дидух, Г. В. Дидух // Зб. наук.пр. ОНАХТ. - Одеса: OНАХТ, 2008. - Вип. 33. - С. 147-153.

21. Дідух Н. А. Наукові основи використання синбіотичних комплексів з чистими культурами Bifidobacterium Iongum у виробництві ферментованих функціональних молочних продуктів / Дідух Н. А. // Молочное Дело. — 2008. — № 3. - С. $21-23$, — № 4. - С. 52 - 54; № 5. - С. 38-39.

22. Власенко В. В. Сучасний стан та перспективи виробництва кисломолочних продуктів функціонального призначення [Текст] / В. В. Власенко, А. М. Соломон, Я. Б. Паулина // Харчова наука і технол. - № 4(9). - 2009. - С. 21-23.

23. Патент на корисну модель 54607 UA Україна, МПК А 23 C 9/00. Кисломолочний десертний продукт / А. М. Соломон, В. В. Власенко, А. К. Д’яконова. — № 201010363; Заявл. 25.08.2010; Опубл. 10.11.2010, Бюл. № 21. — 6с.

24. Власенко В. В. Визначення пробіотичної складової для десертних кисломолочних продуктів функціонального призначення / В. В. Власенко, А. М. Соломон, Г. В. Дідух та ін. // Харчова наука і технологія. — 2010. — № 13(4). — С. 69-71.

\section{ОБОСНОВАНИЕ СОСТАВА И РАЗРАБОТКИ ТЕХНОЛОГИЙ ДЕСЕРТНЫХ ФЕРМЕНТИРОВАННЫХ ПРОДУКТОВ ФУНКЦИОНАЛЬНОГО НАЗНАЧЕНИЯ С ИСПОЛЬЗОВАНИЕМ РАСТИТЕЛЬНЫХ НАПОЛНИТЕЛЕЙ}

\section{А. М. Соломон \\ Винницкий национальній аграрнйй университет}

Т. В. Семко

Винницкий торгово-экономический институт Киевского национального торгово-экономического университета

\section{Г. М. Ножечкина-Ерошенко}

Полтавская государственная аграрная академия

В статтье научно исследованы и обоснованы состав про- и пребиотиков, влияние бифидостимулирующей составляющей и стабилизирующей системы на показатели качества фрерментированных десертных продуктов, разработаны технологии кисломолочных десертов на основе консориума бифидо- и лактобактерий. Проведеные испытания позволили разработать рецептуры и технологии производства ферментированных десертов на молочной и молочномучной основе, с использованием бифидобактерий и лактобактерий, а также бифидостимуляторов, структурообразователей и фрруктово-ягодных наполнителей, которые сохраняют высокую биологическую ценность, нежную структуру,вкус и аромат в течении 15 дней. 